\title{
THE PROVENANCE OF RAW MATERIALS FOR THE MANUFACTURE OF A KNIGHT STOVE FROM PETROV, BRNO
}

\author{
MARTIN HLOŽEK - HANA JORDÁNKOVÁ - IRENA LOSKOTOVÁ
}

\begin{abstract}
Archaeological research in the complex of the Brno chapter at Petrov yielded a series of greenglazed incised tiles from the ledge of a knight stove (angel the shield-bearer). The tiles were made in 14541457 by a royal workshop in Buda for King Ladislaus the Posthumous. The frequency of the finds of the remains of these stoves in Brno (different types from at least eleven locations) led to the exact determination of the provenance of the Petrov series, the main objective being to contribute to a deeper knowledge of the forms of transport of luxury tile stoves at the onset of the late Middle Ages. The tiles were subjected to micropetrographic analyses, which showed that local ceramic material rich in grog was used for their manufacture. In all probability, it came from the vicinity of Petrov. Analyses of the glazes by means of XRF and SEM-EDX revealed no traces of alkali components in the green glazing on the surface of the tiles, and confirmed that primarily $\mathrm{PbO}$ was used as a melting agent. The specific green tint was achieved by the addition of 2-3.5\% of $\mathrm{CuO}$. The tiles were fired in chamber kilns at temperatures around $1000^{\circ} \mathrm{C}$.
\end{abstract}

Key words: stove tiles - micropetrographic analyses - glazes - ceramic material-Middle Ages.

\section{Provenience surovin $k$ výrobě rytírských kamen z brněnského Petrova}

Abstrakt: Z archeologického výzkumu v areálu brněnské kapituly na Petrově pocházi soubor zeleně glazovaných prořezávaných kachlů z řmsy tzv. rytírských kamen (anděl štitonoš), vyráběných v letech 1454-1457 budínskou královskou dílnou pro Ladislava Pohrobka. Četnost dokladů pozůstatků těchto kamen $v$ brněnských nálezech (různé typy z nejméně jedenácti lokalit) vedla $k$ exaktnímu ověrení provenience petrského souboru s cilem přispět k hlubšimu poznáni forem transportu luxusních kachlových kamen na prahu pozdniho středověku. Kachle byly podrobeny mikropetrografickým rozborům, které prokázaly, že k jejich výrobě byla použita mistni keramická surovina bohatá na ostřivo, jež byla s největši pravděpodobností těžena v okoli Petrova. Rozbory glazur metodami XRF a SEM-EDX odhalily, že zelená glazura na povrchu kachli̊ obsahuje vysoké procento PbO. Specifického zeleného odstínu bylo dosaženo přidavkem 2-3,5\% CuO. Kachle byly vypáleny v komorových pecích při teplotách kolem $1000{ }^{\circ} \mathrm{C}$.

Klíčová slova: kamnové kachle-mikropetrografické analýzy-glazury - keramické suroviny - středověk.

\section{Introduction}

Archaeological research in the complex of the Brno chapter at Petrov (Fig. 1) yielded a series of green-glazed incised tiles from the ledge of a knight stove (angel the shield-bearer) made in 1454-1457 by a royal workshop in Buda for King Ladislaus the Posthumous (Holl 1958, 291-299). The frequency of the finds of the remains of these stoves in Brno (different types from at least eleven locations; Loskotová 2011, 88-90) led to the exact determination of the provenance of the Petrov series, the main objective being to contribute to a deeper knowledge of the forms of transport of luxury tile stoves at the onset of the late Middle Ages. In addition, the analysed series was supplemented with selected tile finds from the same context, with emphasis on the motifs with analogies in the Brno milieu so that the identical or different components could support interpretation conclusions regarding the provenance of the knight stoves from Brno.

This study seeks to determine the provenance of raw materials of tiles of a luxury knight stove. The series was subjected to micropetrographic analyses which were to determine whether the tiles were made of ceramic material of Brno provenance and whether there was a connection between the individual samples as regards the material (Gregerová et. al 2010). Selected samples were made into cuts studied under the Olympus BX 51 polarization microscope. With each sample, the representation of the fragments of minerals and rocks was determined, while firing temperature of the tiles was determined on the basis of colour changes in minerals. These issues had been addressed in the first half of the 1990s by I. Holl with knight stoves from Buda 


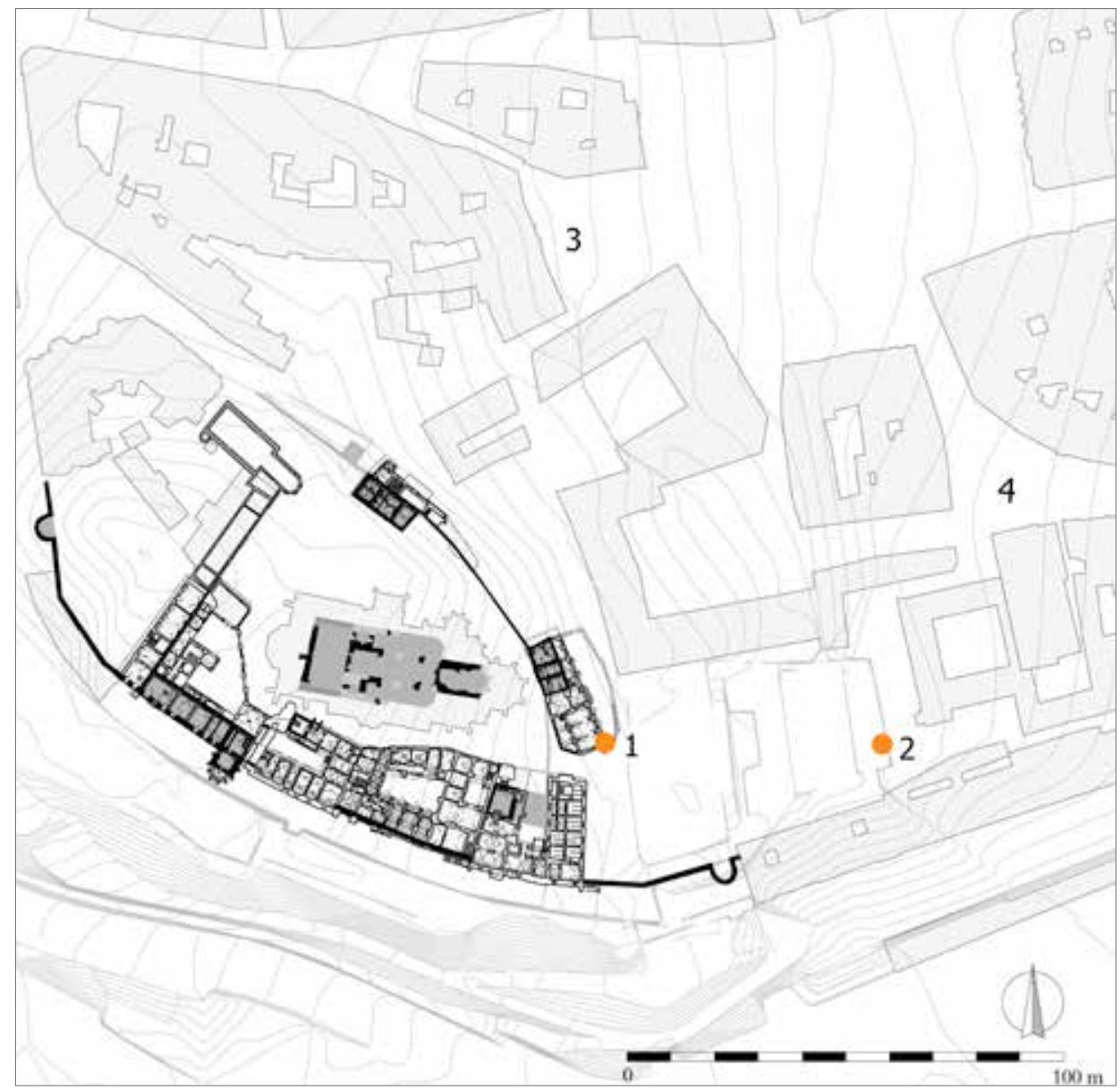

Fig. 1. Brno, Petrov Hill. Black - late medieval structures, dark grey - presumed extent of built-up area, light grey - present built-up area. After Borský-Holub-Merta-Peška 2006. 1 - refuse pit, Petrov 2; 2 - potters' kilns below Petrov; 3 - potters' market; 4 - coal market.

Obr. 1. Brno, Petrské návrší. Černě - doložené vrcholně stř̌edověké konstrukce, tmavě šedě - předpokládaný rozsah zástavby, světlešedě - zástavba současná. Podle Borský-Holub-Merta-Peška 2006. 1 - odpadní jímka, Petrov 2; 2 - hrnčířské pece pod Petrovem; 3 - hrnčířský trh; 4 - uhelný trh.

(Holl-Balla 1994, 381-404; Holl 1995, 257-293). To analyse the tiles, the researchers used the method of instrumental neutron activation analysis (INAA), which in the first half of the 1990s appeared the most progressive for the determination of the provenance of ceramic, through the determination of trace elements ( $\mathrm{ppm}-\mathrm{ppb}$ ), isotopes and traces of precious soils. Its advantage, and also disadvantage, is high sensitivity, which means that the results can be influenced by inconsistency and even different procedures in the preparation of the samples for analyses. Employing this method, trace elements and elements of precious soils were determined with tiles from Buda and other sites. Based on the statistical assessment of the data, the authors created groups of products with corresponding chemical compositions. Occasional deviations were attributed to the changes in technology, different kinds of sediments in the layers in the mining deposits which might have been mixed, etc. The Hungarian researchers probably did not have the possibility of combining INAA with micropetrographic analyses which would have specified the 
approach to the issues of the technology and provenance of the studied tiles. Unfortunately, the studies do not contain the primary measured data of tiles from Buda and other locations. Owing to the difference in methods, I. Holl's results cannot be compared to the micropetrographic analyses of the tiles from Brno knight stoves.

\section{Context}

The tile series comes from a circular refuse pit located in the south-east corner of the modern-age section of the house at Petrov 2 (no. 274). The fill was divided into three relatively sharply separated chronological horizons, the most recent of which (layers 112, 113 and 231) contained, apart from stove items, also coins placing the final phase of the refuse pit use between the $1520 \mathrm{~s}$ and the 1550s (Procházka 1996, 2; 1997, 185). This period, and especially its beginning, is also acceptable as the decline horizon for the analysed knight stove, which, however, cannot be extended to other tile finds from this context. In contrast to the plentiful collection of knight stove tiles, this group varies in relief and typology and can be dated on the basis of analogies of decorative motifs on the front walls to the period starting approximately in the second half of the 15th century and ending around the mid-16th century when some of the preserved motifs only began to be applied (see further). The researchers presume, also due to the clear horizontal breaks in the fill, the regular emptying of the refuse pit. The number of the preserved specimens of the individual types of tiles from the knight stove supports this theory through its composition. When disposing of waste, the top of the stove got to the refuse pit first, and its major part survived during its subsequent clearing, while tiles from the stove base positioned higher in the pit were removed from it, with the exception of several small fragments which had sunk lower.

\section{Knight stoves}

The analysed tiles come from a knight stove (Fig. 2). These stoves were manufactured in a relatively short period of time, in 1454-1457, by a royal workshop in Buda for King Ladislaus the Posthumous. The dating follows from coats of arms on the crown ledge tile with an angel the shield-bearer and also on some other tiles from this series. The stoves were made in a green-glazed variant, less often non-glazed, in which case red or yellow was used on the shield (possibly red clay). As luxury products, these stoves were installed in

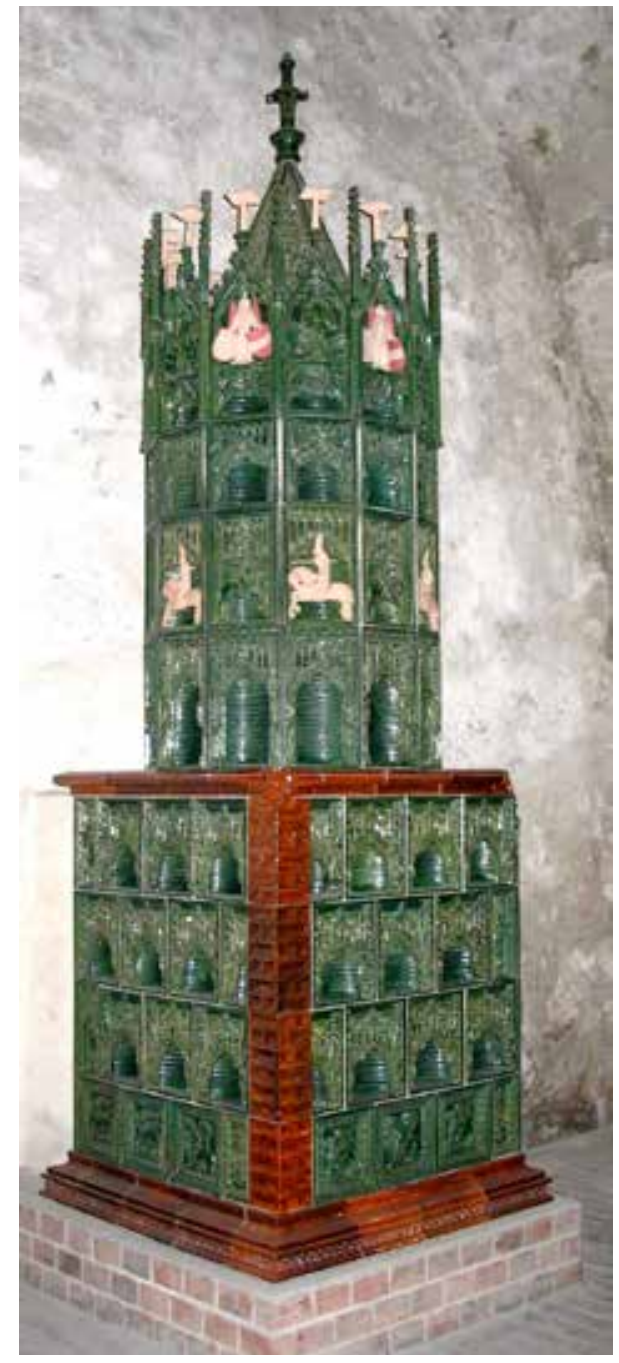

Fig. 2. Reconstructed knight stove, castle exhibition, Budapest. Photo I. Loskotová.

Obr. 2. Rekonstrukce rytířských kamen v hradní expozici v Budapešti. Foto I. Loskotová. 
royal palaces in Hungary as well as outside it, and as royal gifts made their way to the interiors of the king's protégés (Holl 1958, 296). In the Czech lands, the stoves are only reported from a few locations (castles Lipnice and Lichnice, Kobeřice manor, the towns of Brno and possibly Olomouc). Brno boasts the largest collection, with series of stove fragments from as many as eleven locations including Špilberk Castle (Loskotová 2011, 88-90, 103-105). This mass-scale spreading indicates that the tiles were probably not transported and assembled in Brno but were made in one of Brno's pottery workshops, with the use of original matrices or moulds. The local manufacture is also prompted by further fragments whose style and size rank them with the copies or imitations of Buda originals. The crown tile from Petrov (Fig. 3; h. 545, w. 210 incl. side semi-column, depth $110-130 \mathrm{~mm}$ ) is unique among Brno finds; this group stands out due to the number of specimens (at least nine specimens; held by the Brno City Museum, inv. nos. 18/94-231/1-10) and the degree of preservation. One representational specimen of this tile
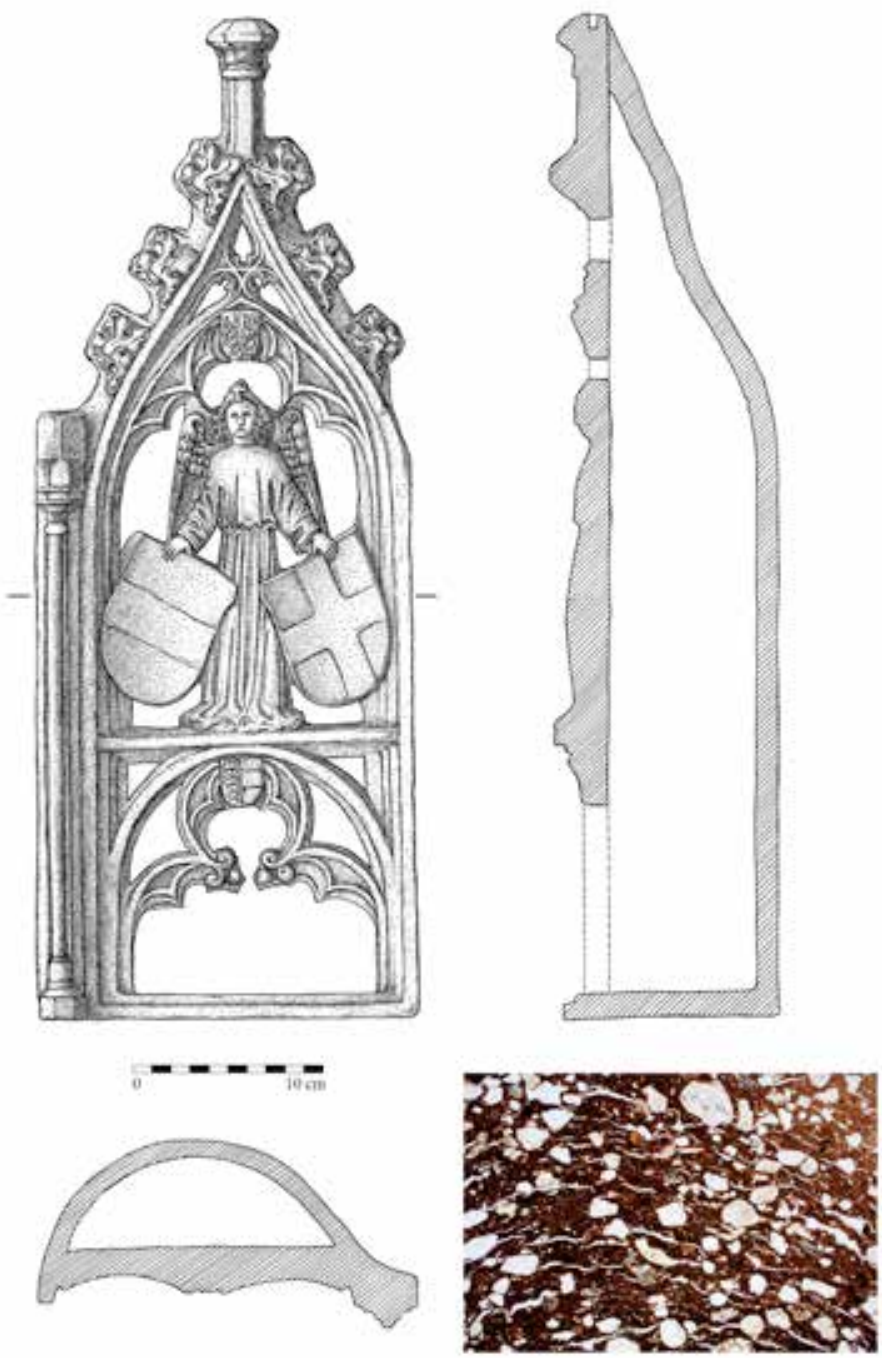

Fig. 3. Knight stove, type 7, Petrov 2, Brno (drawing by L. Chatrná), microstructure of the sample (photo M. Hložek). Obr. 3. Rytířská kamna, typ 7, Petrov 2, Brno (kresebná rekonstrukce L. Chatrná), mikrostruktura vzorku (foto M. Hložek). 
was subjected to a micropetrographic analysis (after Holl 1958, 292 knight stove, type 7). In the grog of this sample, rock fragments identified included quartzite, fine-grain sandstone to siltstone, biotite slate, silicite, amphibolite and aplite. The fragments of minerals mainly included quartz and feldspar (alkali feldspar and plagioclase), less often mica - muscovite and biotite - and rarely also amphibole. The determined mineral association corresponds to the rock formation. The ratio between the pelitic and grog components indicates that the tile was made of brick clay. The firing temperature was higher than $1000{ }^{\circ} \mathrm{C}$. The chemical composition of the green glaze on a beige engobe was determined by the SEM-EDX method and shows the presence of $\mathrm{SiO}_{2} 33.25 \%$, $\mathrm{Al}_{2} \mathrm{O}_{3} 2.81 \%, \mathrm{PbO}_{2} 62.25 \%$ and $\mathrm{CuO} 1.69 \%$. From the other knight stove tiles, unlike the almost complete crown (the reconstructed stove in the Buda castle display is crowned with a ledge of twelve specimens with the angel the shield-bearer, tile dimensions: h. 545, w. 190/210/mm; Holl 1971, 182, 201), only fragments from three other types were preserved representing, in high-quality incised form, elements of Gothic architecture. While type 4 (Fig. 4) of rectangular format (h. 380?, w. 210 ? mm, at least two specimens held by the Brno City Museum, inv. nos. 18/94-231/25, $26,27)$ belongs with the extension section of the stove, lower type 3 (Fig. 5; h. 270?, w. $215 ? \mathrm{~mm}$, at least two specimens held by the Brno City Museum, inv. no. 18/94-231/24) could, based on the Buda reconstruction, have been used both for the extension section and the base (Holl 1958, 222, 291-292). A sample from a tile of type 3 was subjected to a micropetrographic analysis. Fragments of rocks in the grog included, in particular, quartzite, metaquartzite and cataclasite. In addition, there was also aplite, amphibolic diorite and mica slate. Minerals included quartz, plagioclase, alkali feldspar and mica, with a minor proportion of amphibole. There were also tiny iron oxide-hydroxide aggregates. The tile was made of brick clay and fired between $900-1000{ }^{\circ} \mathrm{C}$. Type 4 is basically identical with type 3 in its material. The chemical composition of the green glaze on the surface of the tile of type 3 determined by the SEM-EDX method shows the presence of $\mathrm{SiO}_{2} 38.23 \%, \mathrm{Al}_{2} \mathrm{O}_{3} 5.22 \%, \mathrm{PbO}_{2}$ $49.27 \%, \mathrm{~K}_{2} \mathrm{O} 1.10 \%, \mathrm{Fe}_{2} \mathrm{O}_{3} 1.09 \%$ and $\mathrm{CuO} 1.69 \%$. The green glaze on the surface of the tile of type 4 has the following chemical composition: $\mathrm{SiO}_{2} 30.81 \%, \mathrm{Al}_{2} \mathrm{O}_{3} 2.33 \%, \mathrm{PbO}_{2} 61.87 \%$, $\mathrm{CaO} 1.58 \%$ and $\mathrm{CuO} 3.42 \%$. The last type in the collection, 3b (Fig. 6), only represented by
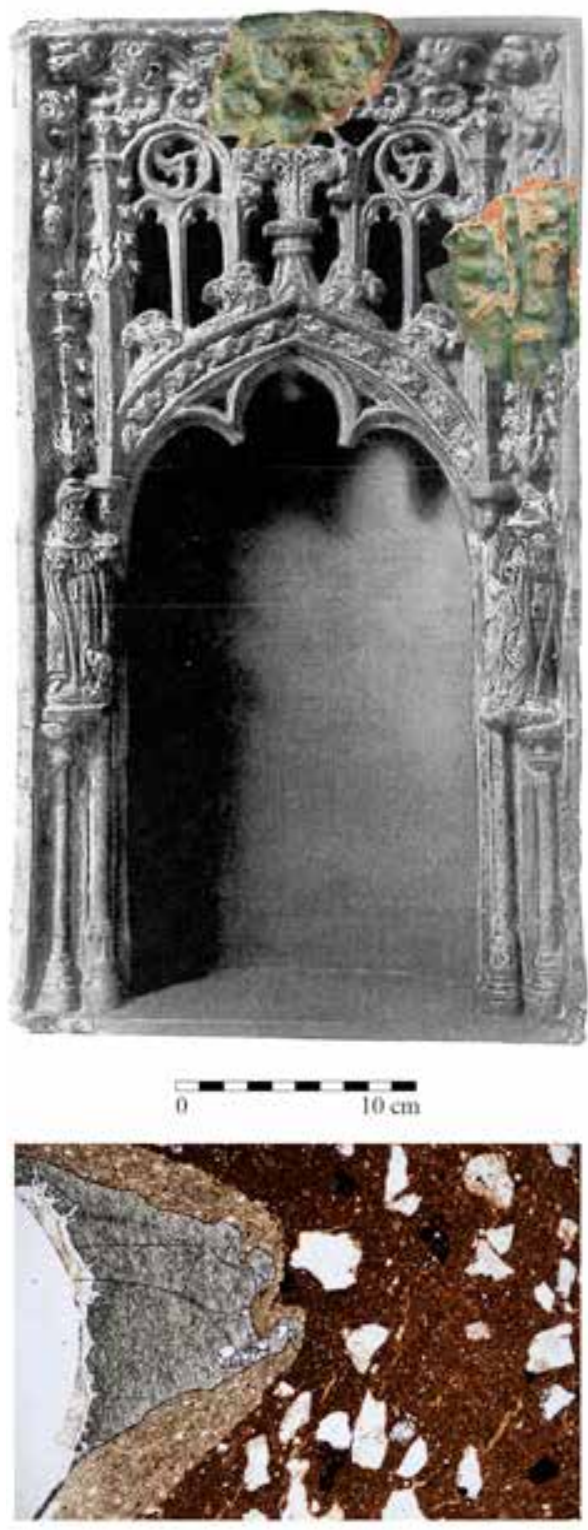

Fig. 4. Knight stove, fragments of type 4, Petrov, Brno (photo V. Nosek), microstructure of the sample (photo M. Hložek), photomontage by Š. Trávníčková.

Obr. 4. Rytířská kamna, zlomky typu 4, Petrov, Brno (foto V. Nosek), mikrostruktura vzorku (foto M. Hložek), fotomontáž Š. Trávníčková. 

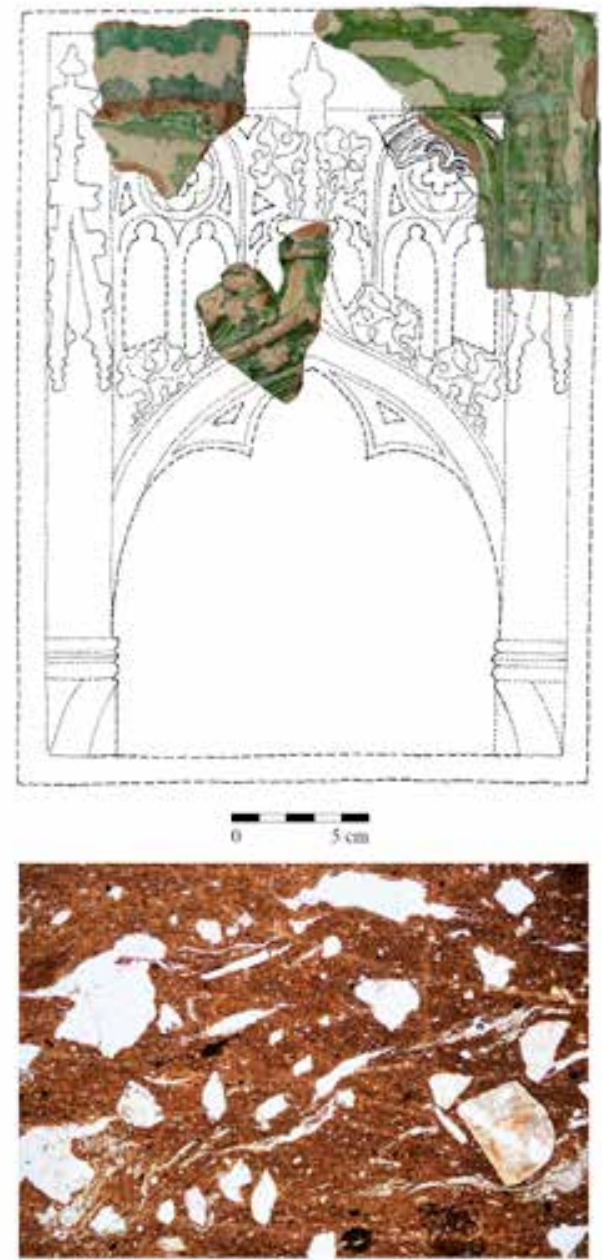

Fig. 5. Knight stove, fragments of type 3a, Petrov, Brno (photo V. Nosek), microstructure of the sample (photo M. Hložek), photomontage by Š. Trávníčková.

Obr. 5. Rytířská kamna, zlomky typu 3a, Petrov, Brno (foto V. Nosek), mikrostruktura vzorku (foto M. Hložek), fotomontáž Š. Trávníčková. the refuse pit which was not very consistent in the last years of its functioning and only regarded the upper section. The origin of the oldest specimens is sought in the last third of the 15th century due to the artistic rendering and some precisely dated analogies, while the most recent ones could have been made in the mid-16th century when the use of the refuse pit was coming to an end. The functioning of the stove counts in decades, though its operation period might have been shorter for various reasons, and it might have been removed not long after its installation.

Specimens selected for comparative micropetrographic analyses were those that occur more often in the Brno milieu and those with some specific features, presumably of local origin.

The lining panel with the relief of St. Barbara (Fig. 7, held by the Brno City Museum, inv. no. 18/94-231-31) was long known only through a body fragment from Dvoŕákova Street 14-16 (Loskotová 2011, 38, 168, 253). The complete relief was only revealed by recent excavations 

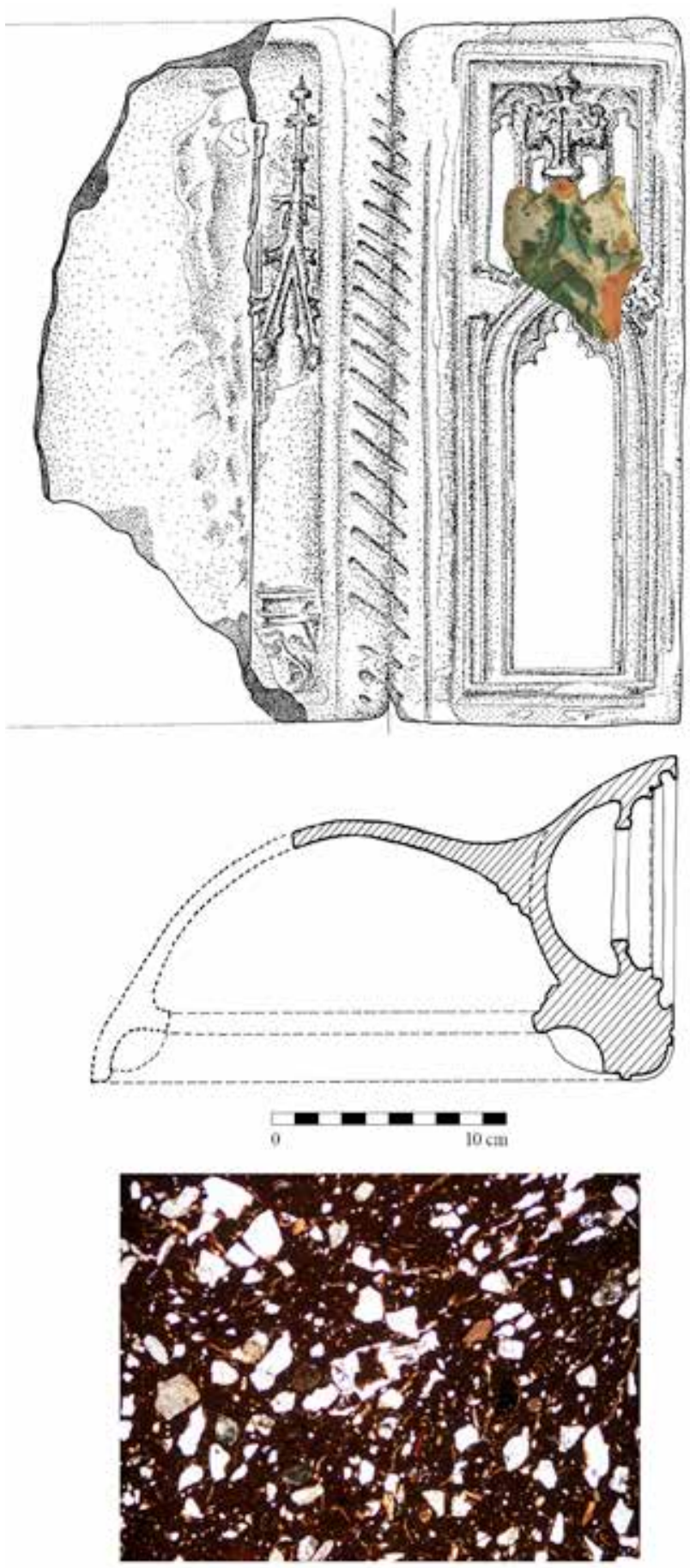

Fig. 6. Knight stove, fragment of type 3b, Petrov, Brno (photo V. Nosek), microstructure of the sample (photo M. Hložek), photomontage by Š. Trávníčková.

Obr. 6. Rytířská kamna, zlomek typu 3b, Petrov, Brno (foto V. Nosek), mikrostruktura vzorku (foto M. Hložek), fotomontáž Š. Trávníčková. 


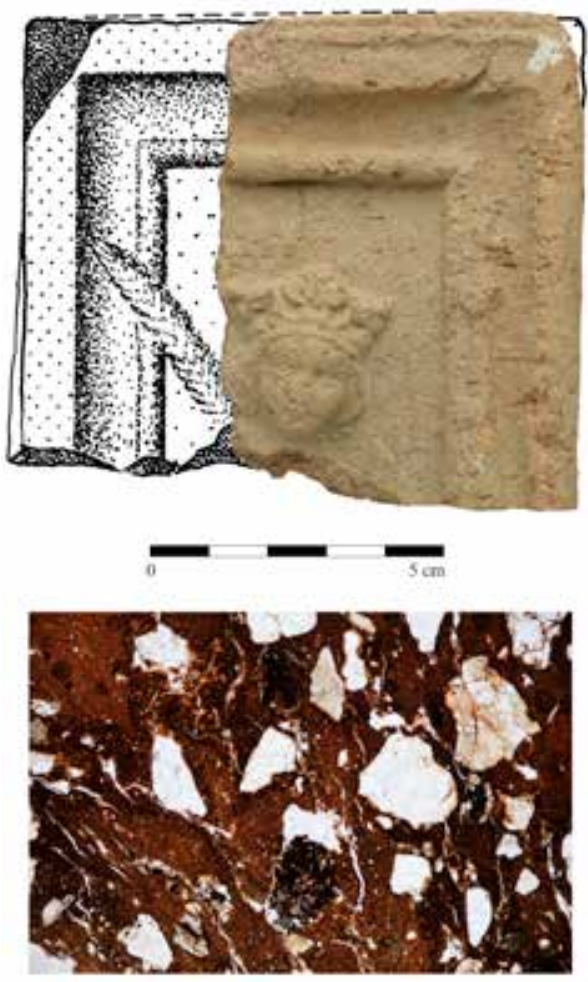

Fig. 7. Fragment of lining panel with the relief of St. Barbara, Petrov, Brno (photo V. Nosek), microstructure of the sample (photo M. Hložek), photomontage by Š. Trávníčková.

Obr. 7. Zlomek obkládací desky s reliéfem sv. Barbory, Petrov, Brno (foto V. Nosek), mikrostruktura vzorku (foto M. Hložek), fotomontáž Š. Trávníčková.

Silesia (Jordánková-Loskotová 2007, 355-359; Loskotová 2011, 107-110), their Brno origin can be presumed not only in connection with the large number of local specimens but also due to the presence of several fragments of moulds for their production in the mentioned series from Veselá Street. The micropetrographic analysis of the fragment of the tile from the Adoration series revealed as the main components of the rock composition of the grog quartzite and mica slate, as well as gneiss. These are accompanied by sandstone and tourmaline aplite. Mineral clasts are dominated by quartz over potassium feldspar, plagioclase and mica. Amphibole and iron oxidehydroxide aggregates occur sporadically. The tile was made of loess or brick clay, the firing temperature reached $800-900^{\circ} \mathrm{C}$. The chemical composition of the green glaze on the surface of the tile from the Adoration series determined by the SEM-EDX method shows the presence of $\mathrm{SiO}_{2}$ $18.32 \%, \mathrm{Al}_{2} \mathrm{O}_{3} 3.39 \%, \mathrm{P}_{2} \mathrm{O}_{5} 11.63 \%, \mathrm{PbO}_{2} 58.11 \%, \mathrm{Cl} 1.96 \%$, $\mathrm{CaO} 5.01 \%$ and $\mathrm{K}_{2} \mathrm{O} 1.58 \%$. This glaze differs substantially from the glazes of knight stoves. It was applied directly on the fired clay without the use of a base engobe. In order not to let the red-fired clay show through affecting the distinct colour of the glaze, the manufacturers employed a simple procedure: they tempered the glaze with whitish bone ash. The resulting glaze thus acquired a specific "poison-green" tint.

1 Our thanks for the study of unpublished material go to Mgr. Pavel Staněk and Mgr. Antonín Zůbek, Ph.D, leaders of research A006/2015 Brno, Janáček Cultural Centre. 

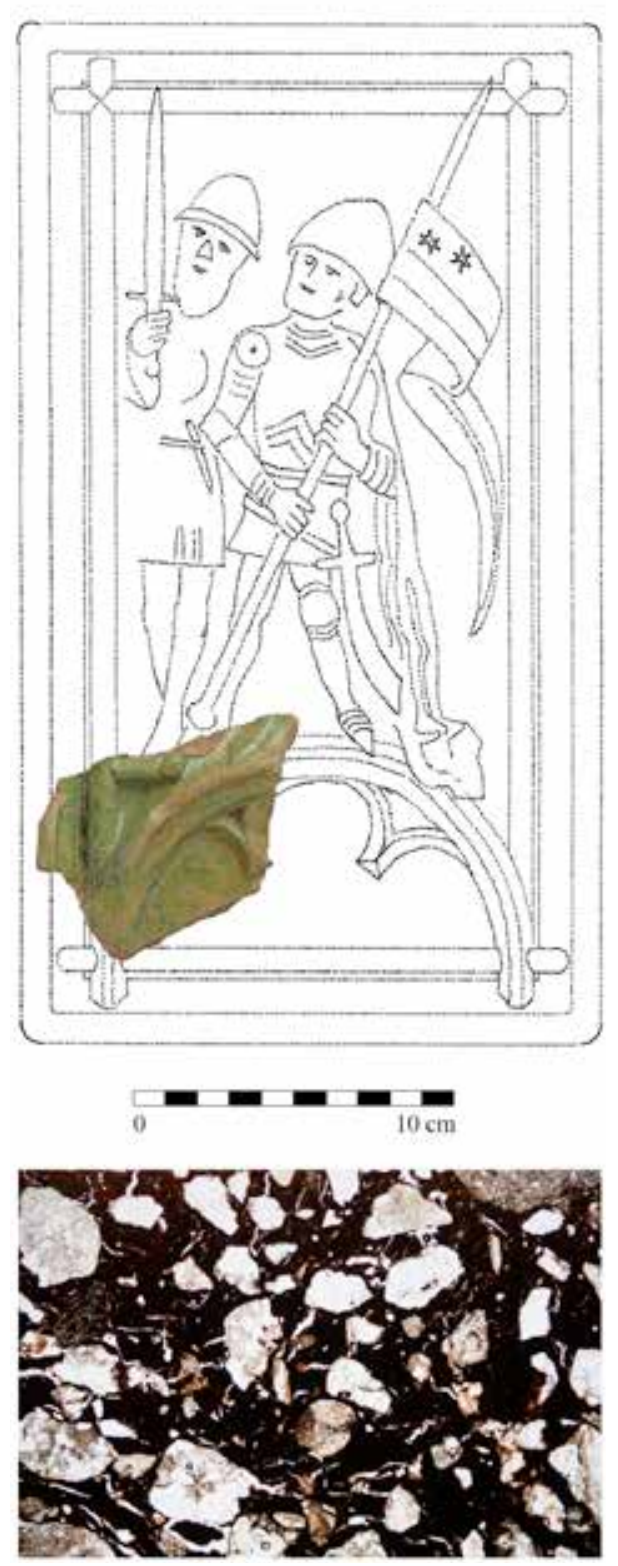

Fig. 8. Fragment of tile from the Adoration series, Petrov, Brno (photo V. Nosek), microstructure of the sample (photo M. Hložek), photomontage by Š. Trávníčková.

Obr. 8. Zlomek kachle ze série Klanění, Petrov, Brno (foto V. Nosek), mikrostruktura vzorku (foto M. Hložek), fotomontáž Š. Trávníčková. graver Georg Pencz reached across Europe, including the Czech lands (comp. Žegklitz 2012, 36-42, 92-98). The Brno relief series dated to the $1530 \mathrm{~s}-1550 \mathrm{~s}$ from at least six sites differs from the other artistic styles employing the renaissance arch through specific architecture with a horizontal structure above the heads of the figures (Loskotová 2012, 666-667). The grog of

The relief of a tile with the allegorical motif of a guilty lion reflects artistic elements of the final phase of the Hungarian and Swiss production circle, and is dominated by a central rosette (Loskotová 2011, 49-51, 176, 258). It appears that it was in Brno where its radical innovation occurred, as indicated by the frequency of finds from at least six locations. The strongest argumentation potential among them is held by kiln no. 2 from Kapucínské náměstí Square from the last quarter of the 15th century (Nekuda 1963, 73, 76). The occurrence of these tiles is not restricted to Brno. Individual finds are also reported from Vyškov, where a rosette in the centre of the relief was preserved, and from Olomouc in central Moravia. Somewhat surprisingly, several specimens are found in the archaeological collection of Muzeum Śląska Cieszyńskiego, Poland. The analysed Brno fragment (Fig. 9; held by the Brno City Museum, inv. no. 18/94-231/37) only shows a small section of the motif which, however, was identified due to a clearly preserved zig-zag line (meander) (comp. a complete specimen from Panská Street 6, to which the fragment from Petrov is compared). The fragment with the allegorical motif of a guilty lion contains the following rock fragments in the grog: clasts of quartzite, metaquartzite, cataclasite to mylonite. These are accompanied by mica slate (phyllite?), slate with graphite, aplite and fine-grain psammite. A micropetrographic analysis revealed that the grog also contained fragments of minerals from the following rocks: quartz, alkali feldspar, plagioclase and mica. Amphibole is accessoric, while pyroxene is very rare. Iron oxide-hydroxide aggregates were identified as well. The tile was made of brick clay and fired between 900 and $1000{ }^{\circ} \mathrm{C}$.

Renaissance tiles are represented in the analysed series by a fragment from the series of biblical heroes determined on the basis of characteristic architectural framing (Fig. 10; held by the Brno City Museum, inv. no. 18/94-231/19). The popularity of these motifs inspired by fictitious portraits from the workshop of the Nuremberg painter and en- 

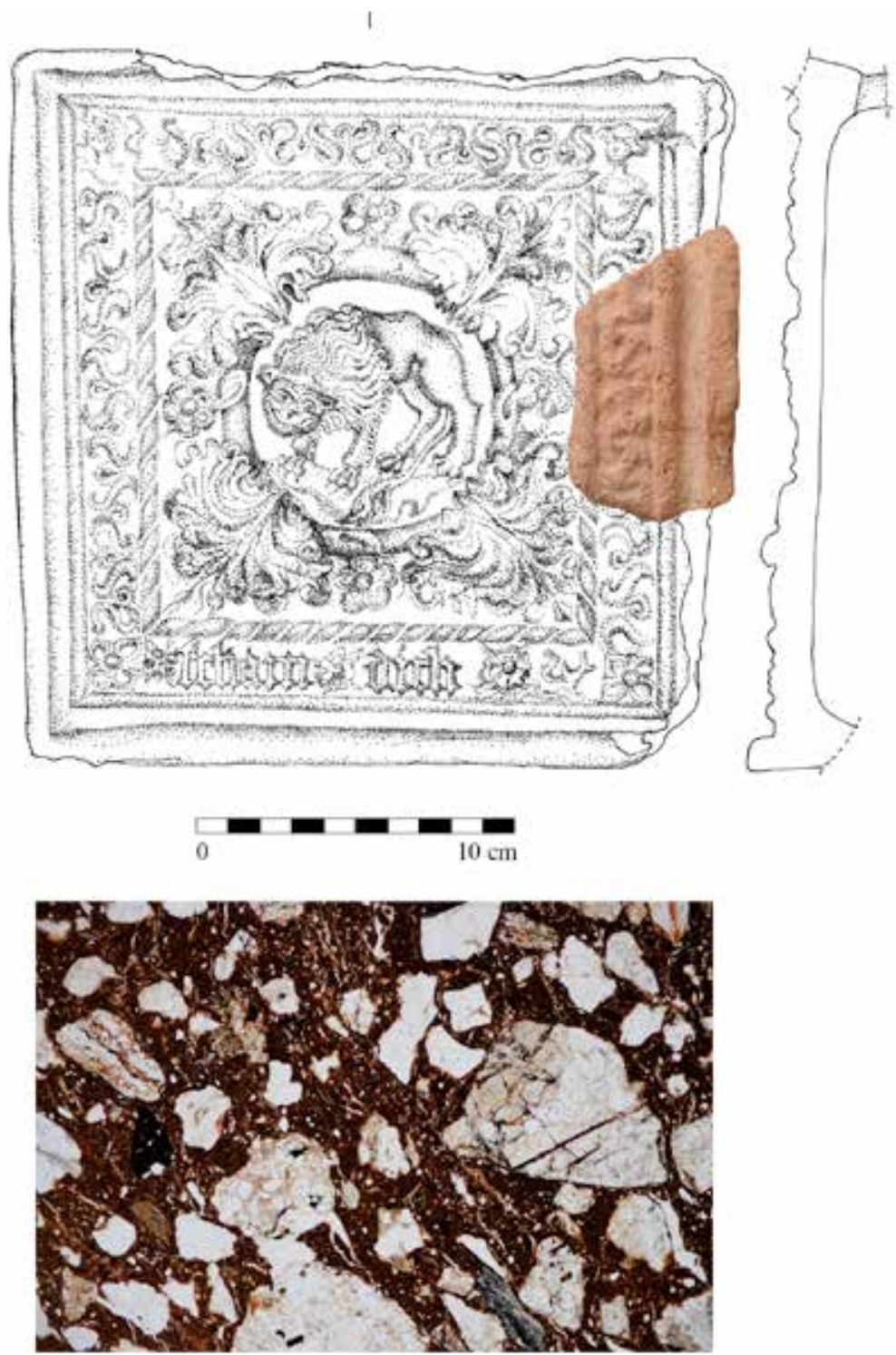

Fig. 9. Fragment of a tile possibly with the motif of guilty lion, Petrov, Brno (photo V. Nosek), microstructure of the sample (photo M. Hložek), photomontage by Š. Trávníčková.

Obr. 9. Zlomek kachle patrně s motivem provinilého lva, Petrov, Brno (foto V. Nosek), mikrostruktura vzorku (foto M. Hložek), fotomontáž Š. Trávníčková.

the fragments of the tile from the series with biblical heroes is dominated by the rock fragments of quartzite, gneiss, metaquartzite, cataclasite and mica slate. Micropetrographic analyses also confirmed the presence of aplite, siltstone, fine-grain sandstone and greywacke, as well as rare granitoid rocks. The association of mineral grains is dominated by the fragments of quartz and 

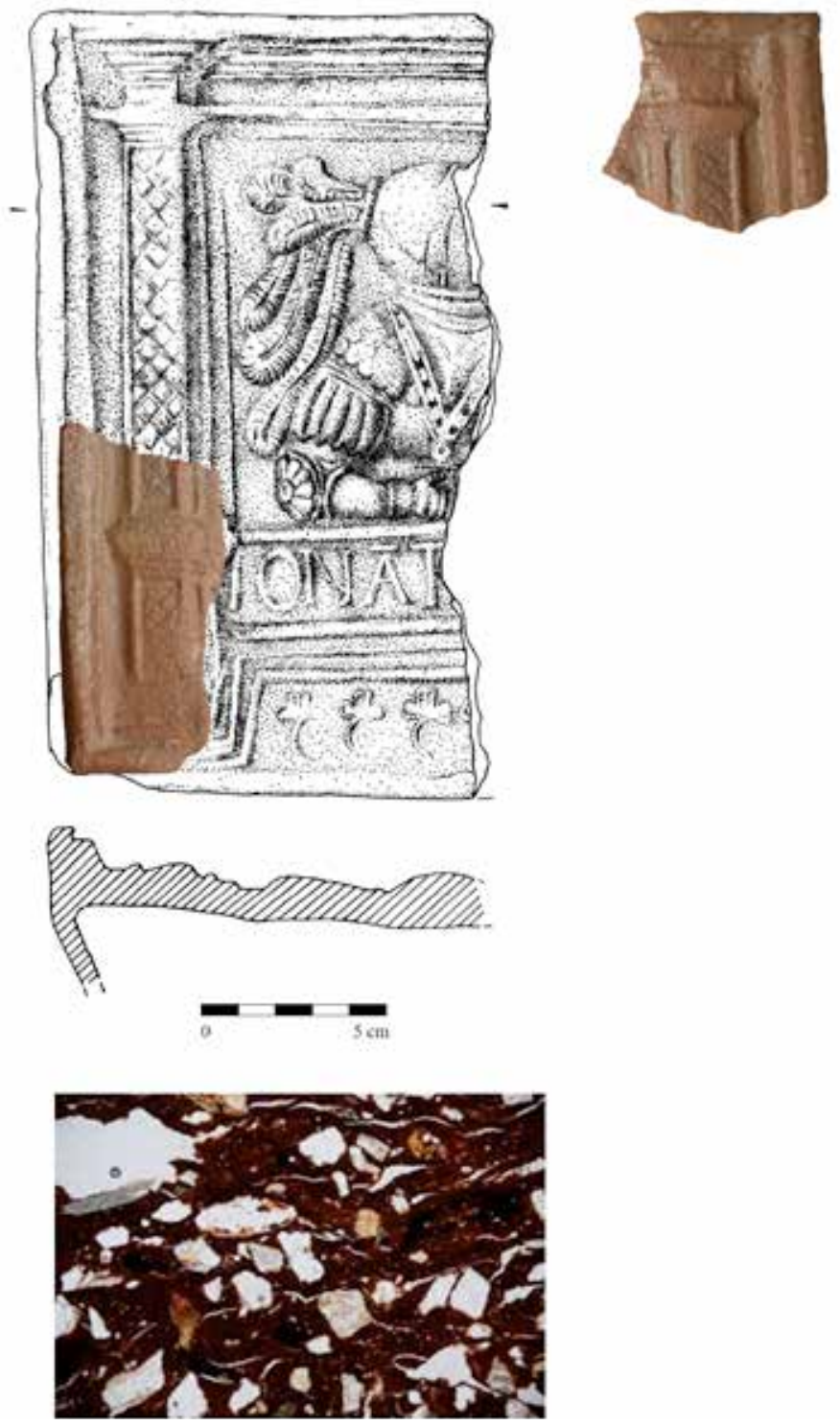

Fig. 10. Fragment of architectural framing of a tile with biblical heroes, Petrov, Brno (photo V. Nosek), microstructure of the sample (photo M. Hložek), photomontage by Š. Trávníčková.

Obr. 10. Zlomek architektonického rámování kachle s biblickými hrdiny, Petrov, Brno (foto V. Nosek), mikrostruktura vzorku (foto M. Hložek), fotomontáž Š. Trávníčková.

feldspar (alkali feldspar, plagioclase) and mica (biotite, muscovite). The tile was made of brick clay and fired between $900-1000^{\circ} \mathrm{C}$.

Starting from the 1540 s, stoves in Brno interiors (reported from at least eleven locations) featured motifs employing the elements of renaissance architecture enlivened by fantastic figures of dolphins (Jordánková-Loskotová 2010). In the refuse pit in Petrov, fragments from at least 
four specimens were identified (Fig. 11; held by the Brno City Museum, inv. nos. 18/94-231/21, $29,30,34,35,38-40,42,45)$, bearing a specific handwriting of the Brno style of the motif. A similar, not identical, and smaller series comes from Dambořice, south Moravia (Menoušková 2004, 165-172). The micropetrographic analysis of the fragment of the tile proved in the grog the presence of quartzite, metaquartzite, cataclasite, gneiss and mica slate. The rock association was supplemented with fragments of aplite, granitoid rocks and fine-grain sediments (fine-grain greywacke, sandstone with clay matrix, sandstone with Fe and siltstone). Mineral clasts were dominated by fragments of quartz over feldspar and mica. Amphibole was exceptional. The tile was made of brick clay and fired at a temperature exceeding $900{ }^{\circ} \mathrm{C}$.

The last in the analysed series are two geometrically segmented tiles that first occurred in Brno in the mid-16th century at the earliest. They are copies of popular Anabaptist tiles

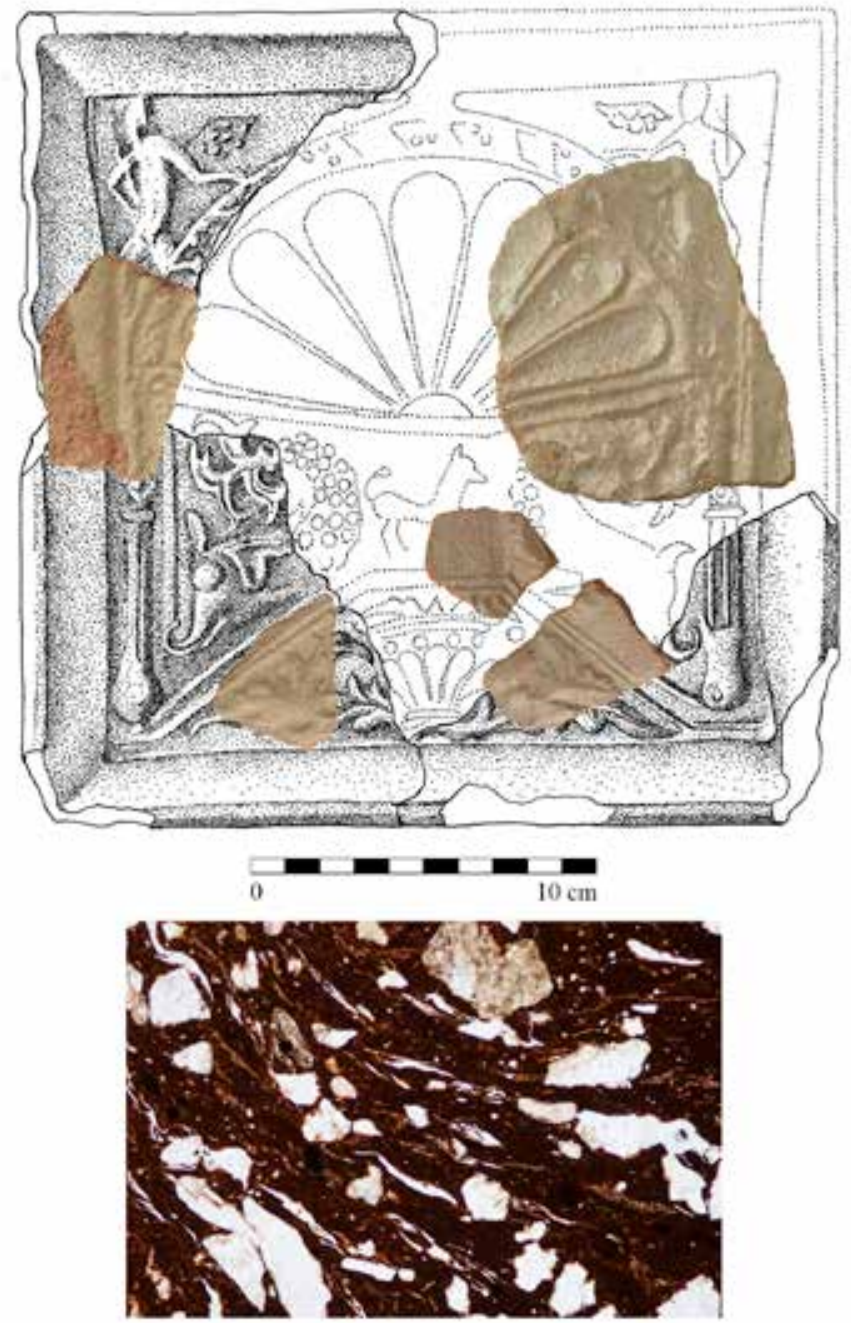

Fig. 11. Fragments of tiles with the motif of dolphins, Petrov, Brno (photo V. Nosek), microstructure of the sample (photo M. Hložek), photomontage by Š. Trávníčková.

Obr. 11. Zlomky kachlů s motivem delfínů, Petrov, Brno (foto V. Nosek), mikrostruktura vzorku (foto M. Hložek), fotomontáž Š. Trávníčková. 
with a medallion-shaped pit (comp. Pajer 1983, 103-109), represented in the Petrov refuse pit by fragments from at least two specimens (Fig. 12; held by the Brno City Museum, inv. nos. 18/94-231/16), and mirror tiles (Fig. 13) represented by one chamber specimen (held by the Brno City Museum, inv. no. 18/94-231/13) and one wall specimen (held by the Brno City Museum, inv. no. 18/94-231/11). Both these types in non-glazed, mica-covered, green-glazed variants or painted in white belong with common early modern-age stove products, not only in Brno. The tile with a medallion-shaped pit contains rock fragments of quartzite, metaquartzite, cataclasite to mylonite and mica slate (gneiss). Granitoids occur sporadically. The main components of the grog are fragments of minerals, chiefly quartz, less often mica, plagioclase and alkali feldspar. There were also tiny iron oxide-hydroxide aggregates. Amphibole is accessoric. Mirror tiles have the same composition of grog. The rock fragments also included phyllite; the content of

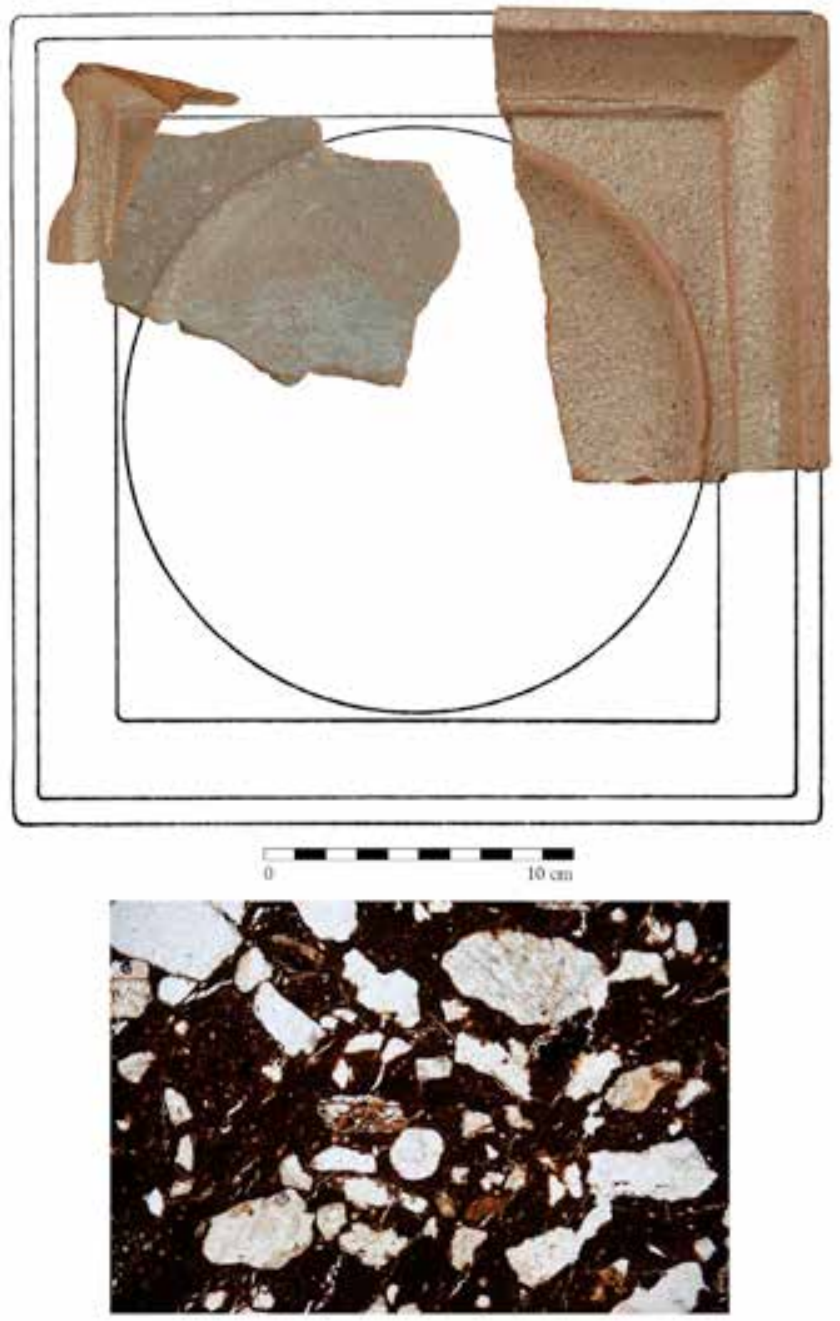

Fig. 12. Fragments of tiles with medallion-shaped pit, Petrov, Brno (photo V. Nosek), microstructure of the sample (photo M. Hložek), photomontage by Š. Trávníčková.

Obr. 12. Zlomky kachlů s medailonovým zahloubením, Petrov, Brno (foto V. Nosek), mikrostruktura vzorku (foto M. Hložek), fotomontáž Š. Trávníčková. 


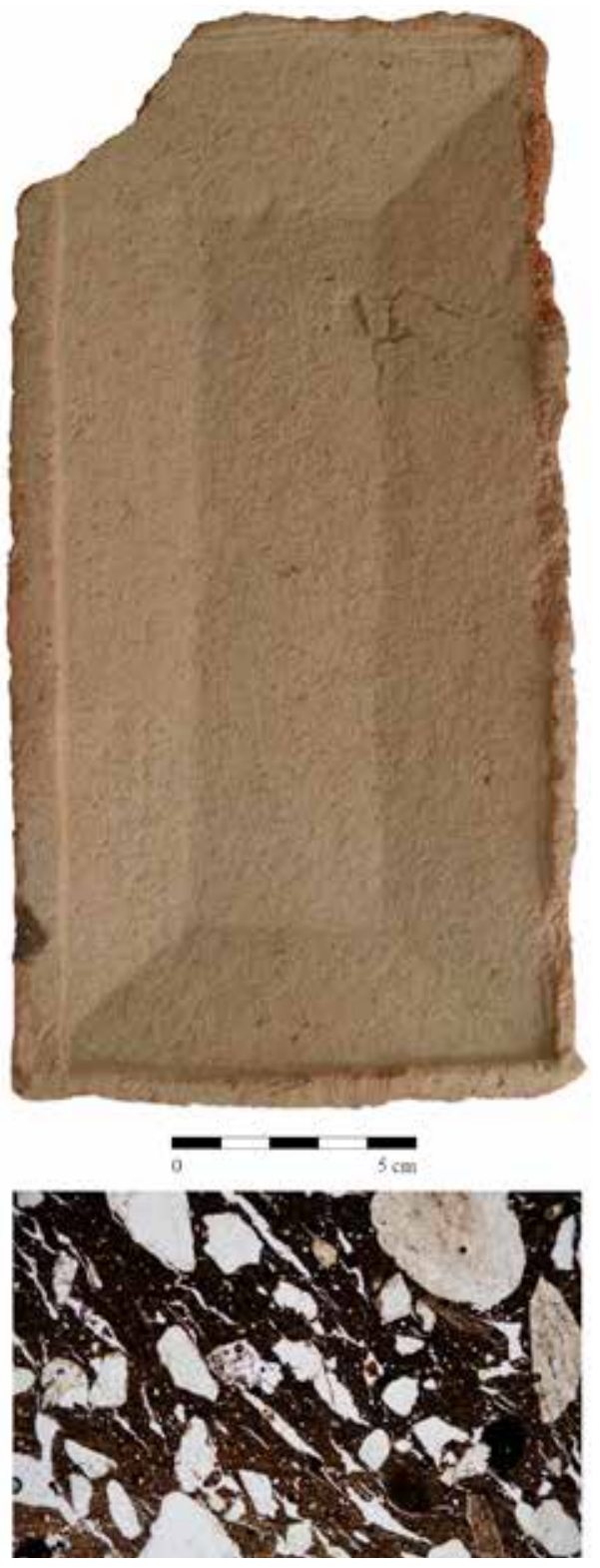

Fig. 13. Body fragment of a mirror tile, Petrov, Brno (photo V. Nosek), microstructure of the sample (photo M. Hložek), photomontage by Š. Trávníčková.

Obr. 13. Torzo zrcadlového kachle, Petrov, Brno (foto V. Nosek), mikrostruktura vzorku (foto M. Hložek), fotomontáž Š. Trávníčková. iron was very low (Fe aggregates). Both these types of tiles were made of brick clay and fired at temperatures $900-1000{ }^{\circ} \mathrm{C}$. In terms of material, they are almost identical.

\section{The Brno Collegiate Chapter at Petrov}

The Brno Collegiate Chapter was established on 7 March 1296 at the Church of Sts, Peter and Paul on Petrov Hill, by Olomouc Bishop Dětřich from Jindřichův Hradec (with the approval of the Olomouc Chapter), in regard to the previous patronage rights of the abbess of the Cistercian convent in nearby Tišnov (Šrámek 2014, 161-162). The two priests of the parish church (Hartlin and Dětřich) were appointed the first canons, in charge of the religious administration and the duty of permanent residence (Tenora 1925, 340; Jan-Procházka-Samek 1996, 41; Jan 2013, 673-674; Pojsl 2015, 177-178).

The first provost of the new chapter (third in Moravia; Olomouc after 1068, Kroměřiž in 1252) was Petr Angelův de Pontecorvo, a longterm royal notary and canon, and later also the Bishop of Olomouc in 1311-1316 (Tenora 1925, 339-340; Jan-Procházka-Samek 1996, 45-46; Pojsl 2015, 179). The chapter in this period was removed from the rights of the Brno parish priest of the Church of St. James, and the right to appoint provosts at Petrov remained with the Tišnov abbess. The positions in the personnel of the Brno chapter stabilised in the late Middle Ages. John of Luxembourg added in 1331 to the prelate rank of provost another one, that of the dean. The third one was the archdeacon. However, as early as 1482 the Brno archdeaconry was, despite the protest of the chapter, affiliated for good with the Olomouc provostry (Tenora 1934, 19; Jan-Procházka-Samek 1996, 49; comp. also Baletka 2011, 155-156; Hledíková 2011, 20-23). A scholastic was responsible for the education of the clergy and laymen. Apart from these ranks, there were also personates (lifetime benefices) and basic offices (custos, treasurer) (Zlámal 1977, 106107; Baletka 2011, 156-157).

The first masonry buildings were constructed at Petrov in the late 13th century (archaeological research unearthed the remains of masonry in today's houses at Petrov nos. 1, 2, 4, 7 and probably also no. 6). In 1306 the royal town of Brno including the Cathedral of St. Peter was affected by a devastating fire which probably also damaged the houses at Petrov (Borský-Holub-Merta-Peška 2006, 202-203). Brno canons 
had inhabited the houses from the start and also influenced their building form. In autumn 1428, a mandatory synod directive was passed, regarding the holding of the canonry houses which were to be used exclusively by canons (Jan 2013, 690).

The number of canons was not strictly defined and varied over the years, stabilised in the 17 th century. The chapter admitted new members by selection, on the basis of a papal provision or a nomination from the governing authorities. Some canon offices also involved related prebends such as church patronage and subsidies from the town and the country (Jan 2013, 683). In contrast to the Olomouc chapter, the economic base of the Brno chapter at Petrov was rather modest. The property of the chapter and the provostry was originally referred to as the Estate of St. Peter and was jointly administered (Tenora 1934, 19). The yields were divided among canons (Budský 2006, 54). ${ }^{2}$ The property of the provost and later also the dean was subsequently separated. A hundred years after the establishment of the Brno chapter and in accord with the Olomouc chapter statutes, in 1392 Brno Provost Ditwin of Vratislav ruled that the entire joint property of the chapter would be divided among prebendatory canons into nine "obedience" parts, of which each would administer one. At the same time, the residence duty of the canons was changed to either permanent residence in Brno for six months without interruption, or seven months with a break, within a single year (Jan-Procházka-Samek 1996, 53-54, 68-69; Jan 2013, 684).

Written records indicate the possible numbers of canons. Nine collegiate canons are reported at the end of the 14th century. A century later there were between twelve and fifteen, while in the 1530 s as many as twenty (based on information from a church manuscript). A hundred years later, the number of canons settled at ten (Tenora 1934, 19-20; Jan-Procházka-Samek 1996, 6566; Jan 2013, 689-690). The rights of the canons, as well as their duties, depended on their position, and were different for resident members of the chapter and non-resident ones. The rights of the resident canons included a right for a house. Its provision was connected with installation in office. Presumably, this custom of the Olomouc chapter can be, with a slight modification, also extended to Brno. When a canon's house was vacated (usually after the owner died, less often after resigning for health reasons), the other members of the chapter could apply for it, if it appeared more comfortable than the houses they currently inhabited. However, the allocation of the empty houses always depended on the years of service (Jasioková 1993, 15-16).

The sequence of the owners (or users) of the canonry houses at Petrov is yet to be put together. The chapter archive from the Middle Ages and the early modern age was destroyed in 1643 during the Swedish siege of Brno. Records in the preserved tax registers (from the years 1375-1634) contain no information either, as the last Přemyslid King Wenceslas III in 1306 first confirmed the existing rights of the collegiate chapter, and at the same time ordered the provincial Moravian officers and the Mayor of Brno not to bother the "provostry house below the church and the houses of the chapter situated between the church and the town walls" with any tax or levy collecting (CDM VI, no. 12, 373; Jan-Procházka-Samek 1996, 47; Jan 2013, 681).

The first and so far also the last list of prelates and canons of the Olomouc chapter in 11311652 was assembled by Metoděj Zemek in the mid-20th century. On the basis of written sources from this study, the Brno canonry can only be traced back to the mid-15th century (chiefly in combination with prebends in Olomouc, Kroměŕíž and Vratislav). By the early 17th century, there had been 50 canons at Petrov; however, it cannot be determined how many of them were resident and non-resident members of the chapter (Zemek 1999; Baletka 2011, 152-153).

When asking who might have commissioned the knight stove in the second half of the 15 th century in today's house at Petrov no. 2, the answer will only be brief due to the absence of written sources. It is difficult to link the names of the known canons with the individual houses, and the authors have thus put forward a hypothetical list of those who might have ordered the stove.

2 While prebendatory canons had a steady income from the yields of their prebends which they received in full, non-prebendatory canons could only draw "portions", i.e. payments for a participation in masses and other services, or could acquire "obedience" - a partial yield from the chapter property. Each canon was only entitled to one prebend, while obedience could be cumulated. 
Jan of Lomnice at Náměšt' (Dvorský 1908), a Moravian aristocrat (bachelor of law, papal chamberlain, provost of the Olomouc chapter 1451, administrator of the Olomouc bishopric 1457, Brno canon in 1457-1460, † 1464); Mikuláš Petř́kův from Brno (recorded in 1463).

The names of the canons under whom the knight stove at Petrov was removed and disposed of are equally hypothetical.

Wolfgang Goschko (resident canon in 1500-1530); Isidor of Hostim (recorded in 1500); Martin Pavlův Horčička called Sinapius (university education - Master, Olomouc canon in 1495, resident canon in Brno in 1501, chapter notary, $\dagger$ 1510); Lukáš Schmid (recorded in 1507).

Among the above names of the members of the Brno chapter, the social status can only be determined with Jan of Lomnice who came from the lineage of the lords of Lomnice at Náměšt'. In the 15th century the number of applicants for the church office with academic degrees either from Prague university or abroad (Vienna, Krakow, Padua, Bologna, Rome) increased. The high cost of university education indicates a high social status (members of lower gentry or the aristocracy, sons from rich burgher families). Apart from work in the church administration, many of them were also active in the public domain; for example, as scribes of the Brno provincial register held by the Church of St. Peter until the late 15th century (Jan-ProcházkaSamek 1996, 50).

\section{Conclusion}

In the assessed series, the authors analysed four fragments of different types of tiles from a knight stove. The raw material is best represented by a sample of type 7 (Fig. 3) made of high-quality material with a large amount of coarse grog which contains amphibole and amphibolites. This raw material was probably mined by potters settled below Petrov in the vicinity of their workshops. The ceramic contains a high degree of grog preventing the deformation of the shape of large-format tiles and knight stoves after the removal of the mould and the subsequent drying. The authors expected the other fragments from the knight stove to be made of the same material; however, types 3, 3b and 4 (Figs. 4-6) were made of a slightly different material obtained from places different from that of type 7. For comparison, the series was supplemented with analyses of tiles from the same context (layer) but with different motifs and dating. The comparative series of tiles were made of raw materials from the sediments of the River Svratka which flows through Brno, i.e. from locations situated farther from Petrov. Yet the raw materials of all of them are of Brno provenance characterised by granitoid rocks, mica slate, fine-grain sandstone and others. These raw materials might have been more accessible for the production of the tiles and their quality sufficient for the common formats of c. $220 \times 220 \mathrm{~mm}$. The results of micropetrographic analyses show that for the manufacture of the knight stove, high-quality raw materials found around Petrov were preferred, as they probably proved more suitable for the shaping and incising of the tiles from elaborate moulds with a fine drawing of complex elements of Gothic architecture. The use of moulds made from original matrices from the Buda workshop which the Brno potters had at their disposal is confirmed by metric correspondence between the unearthed tiles and original Hungarian specimens.

This conclusion draws attention to the archeologically investigated potters' kilns in the slope below Petrov dated to the last quarter of the 15 th century or the early 16 th century. Of the four excavated kilns, two were destroyed and the other two (situated above each other) yielded, apart from kitchenware and tableware, also a representational series of tiles which does not contain any fragments of knight stove tiles nor evidence of glazed tile goods. However, their manufacture in a local workshop on the site cannot be ruled out, also due to the small area investigated. The long pottery-making tradition in this area is also supported by written sources. (Nekuda 1963, 70-78). As early as 1352, a potter named Hermann, the margrave's servant, bought a house not far from the mentioned kilns in the Coal Market (today's Kapucínské náměstí 
Square), moving there with his wife Markéta from the nearby Potters' Market (now the upper part of Zelný trh; Flodr 2005, 228, no. 570; Vičar 1965, 254, 279).

This article came into existence with the support of grant project GA17-13967S, The Sources and Distribution of Selected Commodities of Ceramic Production of the High and Late Middle Ages.

\section{Literature}

BALETKA, T., 2011: Olomoucká kapitula v druhé polovině 15. století. In: Kapituly v zemích Koruny české a v Uhrách ve středověku - Olomouc chapter in the second half of the fifteenth century. In: Kapituly v zemích Koruny české a v Uhrách ve středověku. Documenta Pragensia - Supplementa II, 151-159. Praha.

BORSKÝ, P.-HOLUB, P.-MERTA, D.-PEŠKA, M., 2006: Petrské návrší v Brně - poznámky k vývoji zástavby - Petershügel in Brünn - Anmerkungen zur Bebauungsentwicklung, In: Dějiny staveb 2006. Sborník př́íspěvků z konference Dějiny staveb 2006, 200-212. Plzeň.

BUDSKÝ, D., 2006: Metropolitní kapitula pražská jako dvůr v malém. Kariéra a vztahy v prostředí kapituly v letech 1378-1390 - Das Prager Metropolitandomkapitel als Hof im kleinen. Karriere und Verhältnisse im Millieu des Kapitels 1378-1390. In: Dvory a rezidence ve středověku, 53-86. Praha.

CDM VI: Codex diplomaticus et epistolaris Moraviae VI (Chytil, J., ed.). Brunae 1854.

DVORSKÝ, F., 1908: Náměšt’ský okres. Brno.

FLODR, M., 2010: Pamětní kniha města Brna z let 1343-1376 (1379). Brno.

GREGEROVÁ, M. et al., 2010: Gregerová, M.-Čopjaková, R.-Beránková, V.-Bibr, P.-Goš, V.-Hanuláková, D.-Hložek, M.-Holubová-Závodná, B.-Kristová, L.-Kuljovská, Z.-Macháček, J.-Mazuch, M.-Procházka, R.-Škoda, R.-Všianský, D., Petroarcheologie keramiky v historické minulosti Moravy a Slezska. Brno.

HOLL, I., 1958: Közepkori kályhacsempék magyarországon I. - Mittelaterliche Ofenkacheln in Ungarn I, Budapest Régiségei XVIII, 255-257, 291-292.

- 1971: Közepkori kályhacsempék magyarországon II. - Mittelaterliche Ofenkacheln in Ungarn II, Budapest Régiségei XXII, 161-207.

- 1995: Neutronenaktivierungsanalyse mittelalterlicher Ofenkacheln II, Acta Archaeologica Academiae Scientiarum Hungaricae XLVII, 257-293.

HOLL, I.-BALLA, M., 1994: Neutronenaktivierungsanalyse mittelalterlicher Ofenkacheln, Acta Archaeologica Academiae Scientiarum Hungaricae XLVI, 381-404.

JAN, L., 2013: Kapitula u sv. Petra (a Pavla) na Petrově. In: Dějiny Brna 2. Středověké město (Libor, J., ed.), 673-690. Brno.

JAN, L.-PROCHÁZKA, R.-SAMEK, B., 1996: Sedm set let brněnské kapituly, 41-77. Brno.

JASIOKOVÁ, M., 1993: Držitelé kanovnických domů na jižní a východní linii olomouckého Předhradí 1711-1752. Diplomová práce obhájená na Katedře historie FF Univerzity Palackého, Olomouc.

JORDÁNKOVÁ, H.-LOSKOTOVÁ, I., 2007: Kachlová kamna pozdního středověku v královském městě Brně - Spätmittelalteliche Kachelöfen in der Königsstadt Brünn, BMD 20, 325-380.

- 2010: Delfíni v renesančním Brně - Delphine im renaissacezeitlichen Brünn, BMD 23, 25-46.

JORDÁNKOVÁ, H.-LOSKOTOVÁ, I.-MERTA, D., 2004: Odraz domácí války v produkci brněnských kamnářů druhé poloviny 15. století - Widerspeigelung des Heimkrieges in der Produktion der Brünner Ofensetzer in der zweiten Hälfte des 15. Jahrhunderts, AH 29, 581-597.

LOSKOTOVÁ, I., 2011: Brněnské kamnové kachle období gotiky. Disertační práce na ÚAM FF MU. Dostupné z: https://is.muni.cz/th/dnj7u/disertace-kachle.pdf.

- 2012: Brněnské kachle se starozákonními hrdiny - Tiles with Old Testament Heroes from Brno, AH 37, 663-678.

MENOUŠKOVÁ, D., 2004: Nefigurální renesanční kachle z Dambořic - Non-Figural Renaissance Tiles from Dambořice, Slovácko 46, 161-181.

MICHNA, P., 1972: Př́spěvek historické archeologie k dějinám tzv. „královského domu“ v Brně - Ein Beitrag der historischen Archäologie zur Geschichte des sogenannten „Königshauses“ in Brünn, VVM XXIV, 264-269.

NEKUDA, V., 1963: Nálezy středověkých hrnčiřsských pecí na Moravě - Funde von mittelalterlichen Töpferöfen in Mähren, ČMMZ 48, 57-84. 
PAJER, J., 1983: Počátky novověké keramiky ve Strážnici - Anfänge der neuzeitlichen Keramik in Strážnice. Strážnice.

POJSL, M., 2015: Počátky církevní správy na Moravě, biskupství a arcibiskupství v Olomouci. Uherské Hradiště.

PROCHÁZKA, R., 1996: Nálezová zpráva o provedení záchranného archeologického výzkumu Brno - Petrov, č. p. 2, 8. Uloženo v archivu ÚAPP Brno, č. 136/96 - I, 2-3.

- 1997: Brno (okr. Brno-město). Petrov 2, PV 1993-1994, 185.

SMETÁNKA, Z., 1969: K morfologii českých středověkých kachlů - Zur Morphologie der böhmischen mittelalterlichen Kacheln, PA LX, 228-263.

ŠRÁMEK, J., 2014: Kláštery olomoucké diecéze za episkopátu Bruna ze Schauenburka (1245-1281). Rajhradská kauza z roku 1255. In: Jedinec a evropská společnost od středověku do 19. století (Kalous, A.Stejskal, J.-Šrámek, J., edd.), 145-168. Olomouc.

TENORA, J., 1925: Presentační právo abatyší tišnovských na proboštství u sv. Petra v Brně, Hlídka XLII, č. 2, 337-345.

- 1934: Statek sv. Petra. Brno.

VIČAR, O., 1965: Místopis Brna v polovici 14. století, BMD 7, 242-283.

ZEMEK, M., 1999: Posloupnost prelátů a kanovníků olomoucké kapituly od počátku až po nynější dobu. Rukopis, ulož. v Zemském archivu v Opavě, pobočka Olomouc.

ZLÁMAL, B., 1977: Katalog moravských biskupů, arcibiskupů a kapitul staré i nové doby. Olomouc.

ŽEGKLITZ, J., 2012: Prints and other artwork models for motifs on stove tiles from the Czech lands. Renaissance stove tiles as a means for disseminating ideas and culture during the age of Reformation, Studies in Post-Medieval Archaeology 4, 25-112.

\section{Resumé}

\section{Provenience surovin k výrobě rytířských kamen z brněnského Petrova}

Z archeologického výzkumu v areálu brněnské kapituly na Petrově pochází soubor zeleně glazovaných prořezávaných kachlů z římsy tzv. rytířských kamen (anděl štítonoš), vyráběných v letech 1454-1457 budínskou královskou dílnou pro Ladislava Pohrobka. Četnost dokladů pozůstatků těchto kamen v brněnských nálezech (různé typy z nejméně jedenácti lokalit) vedla $\mathrm{k}$ exaktnímu ověření provenience petrského souboru $\mathrm{s}$ cílem přispět $\mathrm{k}$ hlubšímu poznání forem transportu luxusních kachlových kamen na prahu pozdního středověku. V rámci posuzovaného souboru jsme analyzovali čtyři fragmenty různých typů kachlů rytířských kamen a několik vzorků běžnější kachlové produkce ze stejného nálezového kontextu. Za hlavního surovinového zástupce můžeme považovat vzorek typu 7 , který byl vyroben z kvalitní suroviny s hojným množstvím ostrohranného ostřiva, která obsahuje amfiboly a amfibolity. Tuto surovinu pravděpodobně natěžili hrnčíři usazení pod Petrovem v blízkosti svých dílen. Keramická hmota obsahuje vysoký podíl ostřiva, který zabraňoval deformaci tvaru velkoformátových kachlů rytířských kamen po odformování a následném schnutí. Předpokládali jsme, že i ostatní fragmenty rytírských kamen budou vyrobeny ze shodné suroviny, ale ukázalo se, že pro typy 3,3 b a 4 byly použity mírně odlišné suroviny, které tak nebyly natěženy ve stejném hliníku jako surovina pro typ 7. Rozbory glazur kachlů rytíŕských kamen metodami XRF a SEM-EDX ukázaly, že zelené glazury obsahují vysoký podíl PbO. Specifického zeleného odstínu bylo dosaženo př́ídavkem 2-3,5\% CuO. Pro srovnání byl soubor doplněn analýzami kachlů nalezených ve stejném nálezovém kontextu (vrstvě), ale odlišných motivů i datace. Srovnávací soubory kachlů jsou spíše vyrobeny ze surovin náplav Svratky, tedy z míst vzdálenějších Petrovu. U všech lze však konstatovat, že jsou vyrobeny ze surovin brněnské provenience, pro které jsou zejména charakteristické granitoidní horniny, slídové břidlice, jemnozrnné pískovce aj. Tyto suroviny mohly být pro výrobu kachlů dostupnější a jejich kvalita pro běžné formáty ČVS kolem $220 \times 220 \mathrm{~mm}$ dostačující. Výsledky mikropetrografických analýz ukazují, že pro zhotovení rytířských kamen byly preferovány kvalitnější suroviny nacházející se v okolí Petrova, které se pravděpodobně ukázaly vhodnější pro formování kachlů $\mathrm{z}$ detailně a precizně zvládnutých forem $\mathrm{s}$ jemnou kresbou 
složitých prvků gotické architektury. Použití forem vyrobených z původních matric dílny budínské, které museli mít brněnští hrnčíři k dispozici, dokládá metrická shoda nalezených kachlů $\mathrm{s}$ originálními uherskými exempláři. Tento závěr obrací pozornost $\mathrm{k}$ archeologicky zkoumaným hrnčírským pecím ve svahu pod Petrovem, datovaným do poslední čtvrtiny 15. až počátku 16. století. Ze čtyř zemními pracemi zachycených pecí byly dvě zničeny a ze zbylých dvou, situovaných v superpozici, byl získán krom kuchyňské a stolní keramiky i reprezentativní kachlový soubor, který sice neobsahuje žádné zlomky kachlů z rytířských kamen ani doklady glazovaného kachlového zboží, avšak jejich výrobu v předpokládané místní dílně v tomto areálu nelze už vzhledem k malému plošnému rozsahu archeologického výzkumu vyloučit. O dlouhé tradici hrnčířské výroby v tomto prostoru přinášejí totiž svědectví i písemné prameny dokládající zde hrnčíře už v polovině 14 . století.

Př́íspěvek vznikl s podporou grantového projektu GA17-13967S Zdroje a šíření vybraných komodit keramické produkce vrcholného a pozdního středověku.

Mgr. Martin Hložek, Ph.D., Ústav archeologie a muzeologie Filozofické fakulty Masarykovy univerzity, Arna Nováka 1,602 00 Brno, Česká republika, mhlozek@seznam.cz

PhDr. Hana Jordánková, Archiv města Brna, Přední 2, 61800 Brno, Česká republika, jordankova.hana@brno.cz

PhDr. Irena Loskotová, Ph.D., Ústav archeologie a muzeologie Filozofické fakulty Masarykovy univerzity, Arna Nováka 1, 60200 Brno, Česká republika, irena@phil.muni.cz 
